\title{
The Mathematical Model of Salinity Concentration In The Coastal Area of Sampang Distric Using Remote Sensing Data
}

\author{
Siti Zainab ${ }^{1}$, Dian Purnamawati Solin, Hendrata Wibisana \\ Civil Engineering Department \\ Universitas Pembangunan Nasional "Veteran" Jawa Timur \\ Surabaya,Indonesia \\ 12zainab.ts@upnjatim.ac.id
}

\begin{abstract}
Salinity is one of the parameters needed by farm workers and farmers to determine groundwater quality. High salinity values will greatly affect the concentration of ground water and will make plants difficult to grow and develop properly. Coastal areas in the distric of Sampang are good coastal areas and along the south coast are dominated by mangroves which are diverse, and many businesses of saltmaking are also found. The purpose of this study is to create a mathematical model that can provide an overview of the trend of growing groundwater salinity due to seepage from seawater in the Madura strait, where this mathematical model can be used as a reference in the future to predict how much seawater seepage results in an increase or decrease of ground water salinity. The method used to map salinity concentration based on remote sensing data, where the data used is the surface reflectance value of the Aqua Modis Level 2 satellite image that obtained from the earthexplorer.usgs.gov webpage. The data from images satellite were processed with linear and multivariable regression on visible light wave with band $445 \mathrm{~nm}, 530 \mathrm{~nm}$ and $665 \mathrm{~nm}$. The results shown in this research are Aqua MODIS level 2 satellite imagery can be used to provide a preliminary description of mapping the salinity concentration of groundwater in coastal areas. The most optimum wavelength to map salinity concentration is $667 \mathrm{~nm}$ which is in the area of the red band. The mathematical model that best suits the conditions on the coast of Sampang Regency is Sal $=5,923 * \exp \left\{\left(\operatorname{Rrs} \_665\right) * 0,218\right\}$ with a correlation value of $R$ of 0.914 . The conclusion that can be given from this study is that global mapping with satellite image data can provide an overview of the concentration of salinity that occurs over time in the coastal areas of Sampang district, so that in the future it can be used as a reference for groundwater quality in coastal areas or residential areas which is spread along the coast.
\end{abstract}

Keywords - salinity concentration, mathematical model, remote sensing, Sampang distric.

\section{INTRODUCTION}

Salinity is the result of intrusion process of seawater that enters the land through porosity of the soil that is not impermeable Also salinity is a quantity of a parameter that determines the quality of the soil, where the value of the soil is determined by how much seawater has entered the pores of the soil. High salinity value is not suitable for plants, because the high salinity, plants that are generally planted by farmers to support the family economy cannot live or grow well. As is well known that salinity is the content of ions in water, which is the result of a chemical process in the ocean and then carried into the land through a process of seawater infiltration, which occurs in many coastal areas. Research on the content of groundwater salinity has been carried out by experts, with various methods being developed and also involves the development of information technology so that mapping of groundwater salinity can be detected for a wide and global area

The use of information technology also involves the development of analysing and salinity mapping with remote sensing technique, where the technology is a relatively new developed technology particularly in 20 century $[7 ; 14 ; 16]$, The advances of satellite technology which is supported by the ability of sensor to record the image of the earth's surface in multispectral and multi temporal make this technology is possible to be used to analyse and to make further prediction of seawater intrusion impact through the value of salinity which grow in coastal area $[2 ; 9 ; 11 ; 15]$, thus the community who live in coastal area can identify the quality of soil on the coastal area and it is expected that the community could have informed decision making on how to utilize the land.

This study is intended to map and compile an algorithm mathematical model of salinity in coastal areas, and supported by the development of sensor capabilities for data recording, thus the correlation analysis of reflectance values at visible or RGB wavelengths (Red-Green- Blue) that generated from sensors on the satellite to the salinity value in the field, can be done.

The reflectance use of satellite imagery to create mathematical models has been done by several previous researchers to detect the presence of total dissolved solids extract $[4 ; 12 ; 17]$, sea surface temperature $[1 ; 13]$, konsentrasi dari klorofil $[1 ; 10]$ and also pollution of heavy metals in coastal waters and oil spills offshore [5;8], in this study a mathematical model algorithm will be determined which can describe the situation on the coast of Sampang district as the selected area for this salinity study. 


\section{MATERIAL AND METHOD}

The material used for this study was the value of surface reflectance from the object on the earth surface, on the research location, which is captured on Terra Modis satellite. Research location area is in Sampang district, which is located in Madura island (Figures 1.).

\section{A. Research Location}

This study took coastal area of Sampang district in Madura island as research location, with geographical coordinates point $7^{\circ} 7^{\prime} 52^{\prime \prime}$ to $7^{\circ} 17^{\prime} 37^{\prime \prime}$ south latitude and $113^{\circ} 2^{\prime} 51^{\prime \prime}$ to $113^{\circ}$ 23' $31^{\prime \prime}$ east longitude. This location was chosen,

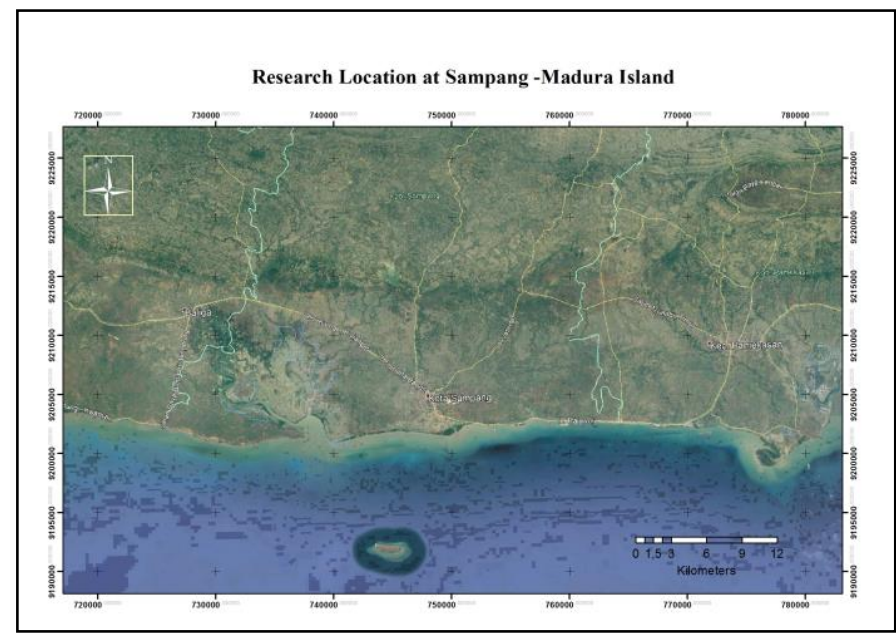

Fig. 1. Research location at Sampang district

as there are some locations point that known as the area that used to produce salt by the local people, thus it can be said that the salinity of these area are high. Besides that, a wide area of ponds and rice fields were found in the area. Along the coastline to the Pamekasan district direction, mangroves are planted to reduce abrasion in the shoreline.

\section{B. Retrieval of satellite images}

The satellite data used to analyse the salinity was from Aqua MODIS satellite image in June 2018 for the area of Java Island and surrounding area, which is retrieved from http://earthexplorer.usgs.nasa.gov/. The acquired file is MYD09A1.A2018121.h29v09.006.2018130033831, where for 1 scene from Aqua Modis has resolution of 500 meters, except for band 1 and band 2 with resolution of 250 meters. Covered areas for 1 scene are Java Island, Bali, Nusa Tenggara Barat, part of Kalimantan and Sulawesi Island. The form of acquired Aqua modis image is show on Figures 2.

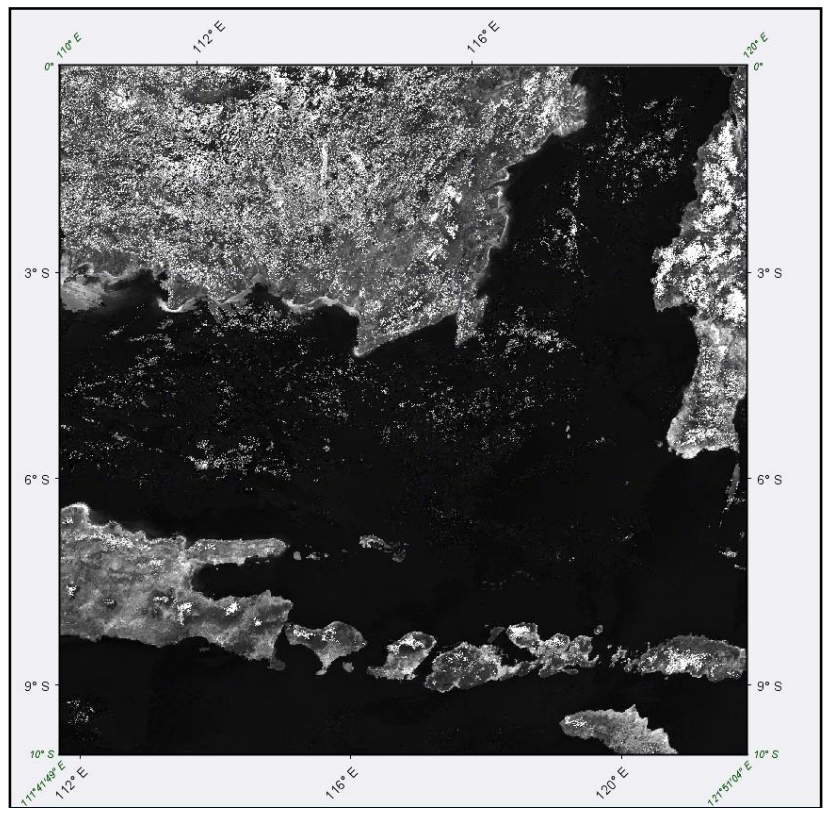

Fig. 2. Scene of Aqua Modis on Area Java and Madura Island.

\section{Algorithm of Mathematical model}

In this study, it is tried to find an algorithm of mathematical models that have a good correlation in which good correlation values are indicated by $R^{2}$ values close to 1 . From mathematical model which is operated in data processing of satellite image will be used approach from 4 models that are commonly used by remote sensing researchers that are linear model $\mathrm{y}=\mathrm{a}+\mathrm{b}^{*} \mathrm{x}$, model eksponential $\mathrm{y}=\mathrm{a}^{*} \exp \left(\mathrm{b}^{*} \mathrm{x}\right)$, model $\log$ arithmic $\mathrm{y}=\mathrm{a}+\ln \left(\mathrm{b}^{*} \mathrm{x}\right)$ and power model $\mathrm{y}=\mathrm{a}^{*} \mathrm{x}^{\mathrm{b}}$. each model would be counted to gain equation which can describe accurate relationship between reflectance from satellite image with it's salinity value.

\section{RESULT AND DISCUSSION}

Data collection in the field resulted in obtained data that salinity on several coordinate points which is measure with GPS navigation. The result of the measurements is shown in table 1. The measurements were carried out as many as 10 points at several points that randomly selected. Then the results measured in the laboratory using the refractometer method and the obtained salinity values in ppt (parts per milion) are presented in table 1 .

The Image of Aqua modis satellite on fig. 2 the image cutting process was done on the area that would be analysed thus a more representative image is obtained, and the cutting results can be seen in in Figure 3.

TABLE I. SALINITY DATA ON EACH EXISTING COORDINATE

\begin{tabular}{|c|c|c|c|}
\hline $\begin{array}{c}\text { Sample } \\
\text { Point }\end{array}$ & Longitude & Latitude & Salinity (ppt) \\
\hline 1 & 113,16676 & $-7,23958$ & 31 \\
\hline 2 & 113,17831 & $-7,23542$ & 34 \\
\hline 3 & 113,18043 & $-7,22708$ & 43 \\
\hline
\end{tabular}




\begin{tabular}{|c|c|c|c|}
\hline $\begin{array}{c}\text { Sample } \\
\text { Point }\end{array}$ & Longitude & Latitude & Salinity (ppt) \\
\hline 4 & 113,18778 & $-7,22292$ & 35 \\
\hline 5 & 113,18990 & $-7,21458$ & 23 \\
\hline 6 & 113,19830 & $-7,21458$ & 18 \\
\hline 7 & 113,19622 & $-7,20625$ & 17 \\
\hline 8 & 113,18678 & $-7,20208$ & 19 \\
\hline 9 & 113,19833 & $-7,19792$ & 38 \\
\hline 10 & 113,17630 & $-7,19375$ & 16 \\
\hline
\end{tabular}

On figure 3 it is seen the appearance form Madura island where Sampang district is located, the cutting process was done by SeaDass 7.2.

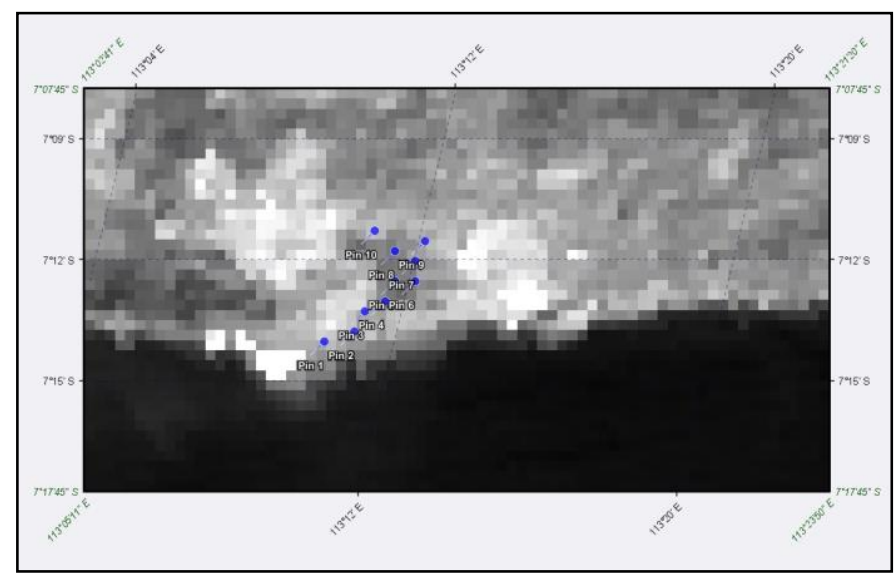

Fig. 3. Cuting result of Aqua Modis image

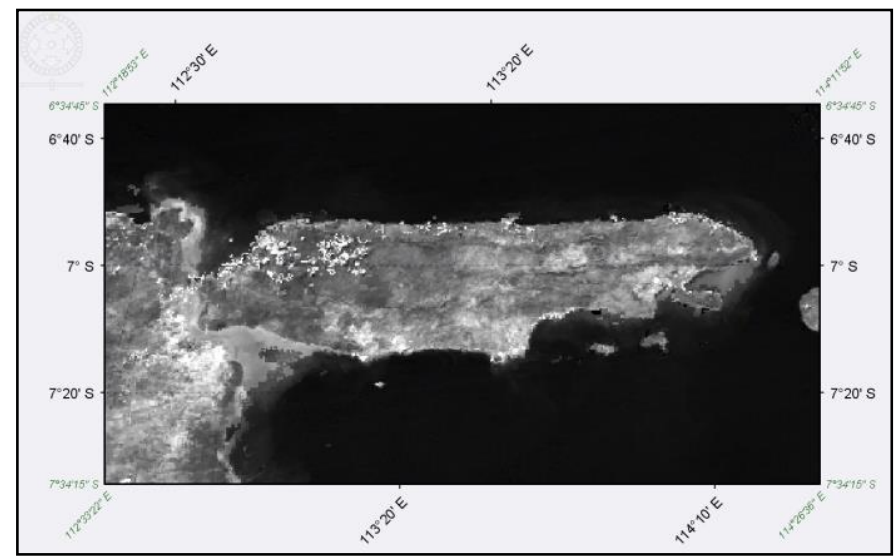

Fig. 4. Sample oint location at Sampang distict

The result for counting and analysing band 3 algorithm is shown on table 4, and from tested mathematical model, the highest R2 correlation value is obtained in the exponential model with a value of $\mathrm{R} 2=0,4048$ where the results of this value indicate that there around $40,48 \%$ field data which is represented in the equation model.
Table 1 shown several sample point location on coordinate that already measured using GPS navigation, and the end result of salinity value is shown on Table 1 after going through the measurements in laboratory by refractometry method. Sample point location on the satellite image is shown on figure 4 , as many as 10-measurement points.

The result and counting of algorithm for each reflectance from Aqua Modis towards salinity value on field resulted in several mathematic model which has various correlation value, where this value shown the relation of mathematical model toward the accuracy of field data from the magnitude of salinity in Sampang district. The algorithm for band 1 is shown on table 2, where the analysed mathematical model is linier model, exponent model, logarithmic, and power model. On table 2 it is seen that the higest $\mathrm{R} 2$ value was obtained from exponent model with R2 value 0,9144 with small difference with other linier model which has $\mathrm{R} 2$ value $\mathrm{R} 2=$ 0,9112 .

TABLE II. ALGORITHM OF MATHEMATICAL MODEL FROM BAND 1 AQUA MODIS

\begin{tabular}{|c|c|c|c|}
\hline No & Model & Math Equation & $\mathrm{R}^{2}$ \\
\hline 1 & Linear & $\mathrm{y}=580,4 \mathrm{x}-11,644$ & 0,9112 \\
\hline 2 & Exponent & $\mathrm{y}=5,9233 \mathrm{e}^{21,855 \mathrm{x}}$ & 0,9144 \\
\hline 3 & Logarithmic & $\mathrm{y}=37,273 \ln (\mathrm{x})+129,03$ & 0,8853 \\
\hline 4 & Power & $\mathrm{y}=1222,5 \mathrm{x}^{1,4155}$ & 0,9037 \\
\hline
\end{tabular}

On table 3 , is the result for counting and analysing of algorithm band 2 , where on table 3 . Is seen correlation value of the highest R2 is obtained on exponent model with value of 0,4232 , this correlation value from band 2 is smaller than the result is shown on band 1 for the same algorithm model.

TABLE III. ALGORITHM OF MATHEMATICAL MODEL FROM BAND 2 AQUA MODIS

\begin{tabular}{|c|c|c|c|}
\hline No & Model & Math Equation & $\mathrm{R}^{2}$ \\
\hline 1 & Linear & $\mathrm{y}=-54,554 \mathrm{x}+38,879$ & 0,3714 \\
\hline 2 & Exponent & $\mathrm{y}=40,839 \mathrm{e}^{-2,189 \mathrm{x}}$ & 0,4232 \\
\hline 3 & Logaritmic & $\mathrm{y}=-4,419 \ln (\mathrm{x})+19,236$ & 0,1969 \\
\hline 4 & Power & $\mathrm{y}=18,313 \mathrm{x}^{-0,185}$ & 0,2437 \\
\hline
\end{tabular}

TABLE IV. ALGORITHM OF MATHEMATICAL MODEL FROM BAND 3 AQUA MODIS

\begin{tabular}{|c|c|c|c|}
\hline No & Model & Math Equation & $\mathrm{R}^{2}$ \\
\hline 1 & Linear & $\mathrm{y}=291,48 \mathrm{x}+16,621$ & 0,3523 \\
\hline 2 & Exponent & $\mathrm{y}=16,688 \mathrm{e}^{11,746 \mathrm{x}}$ & 0,4048 \\
\hline 3 & Logaritmic & $\mathrm{y}=14,316 \ln (\mathrm{x})+76,281$ & 0,5061 \\
\hline 4 & Power & $\mathrm{y}=177,74 \mathrm{x}^{0,5656}$ & 0,5592 \\
\hline
\end{tabular}


Table 5 is describe the result of counting and analysing from band 4 of Aqua modis image, where the analysed model.

\section{TABLE V. ALGORITHM OF MATHEMATICAL MODEL FROM} BAND 4 AQUA MODIS

\begin{tabular}{|c|c|c|c|}
\hline No & Model & Math Equation & $\mathrm{R}^{2}$ \\
\hline 1 & Linear & $\mathrm{y}=281,16 \mathrm{x}+6,0069$ & 0,4668 \\
\hline 2 & Exponent & $\mathrm{y}=11,073 \mathrm{e}^{11,099 \mathrm{x}}$ & 0,5148 \\
\hline 3 & Logaritmic & $\mathrm{y}=24,671 \ln (\mathrm{x})+91,979$ & 0,5503 \\
\hline 4 & Power & $\mathrm{y}=322,74 \mathrm{x}^{0,9657}$ & 0,5968 \\
\hline
\end{tabular}

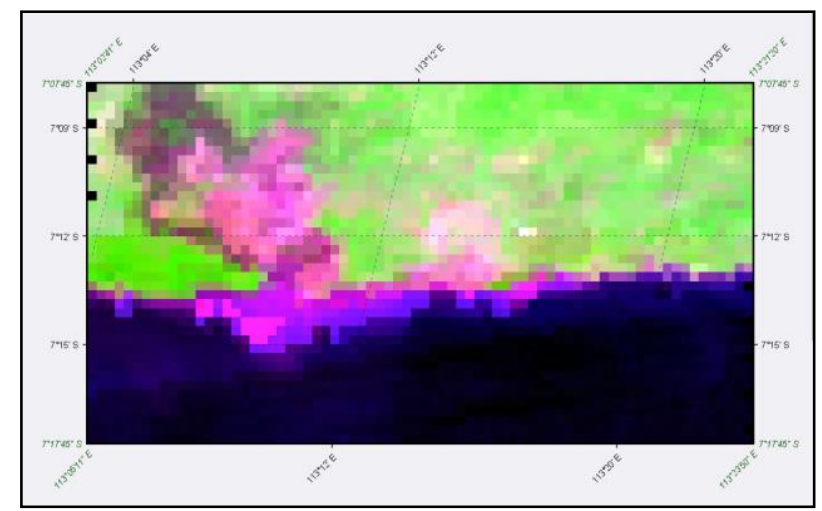

Figure 5. Thematic map of salinity at Sampang district base on Aqua Modis satellite image

It is obtained the highest correlation values of 0,5968 . This value comes from power model altogether different with previous band which show the tendency of highest exponent model, and particularly on this band 4, power model show different result which is different where with this model there are about $59,68 \%$ the field data obtained which can be represented for mathematical model from band 4 .

If all the result from each band of aqua modis image is organize on resume table, the result would be shown as on table 6 .

TABLE VI. RESUME OF MODEL MATHEMATIC FROM ALL BAND IN AQUA MODIS

\begin{tabular}{|c|c|c|c|}
\hline No & Band & Model & $\mathrm{R}^{2}$ \\
\hline 1 & 1 & Exponent & 0,9144 \\
\hline 2 & 2 & Exponent & 0,4232 \\
\hline 3 & 3 & Power & 0,5592 \\
\hline 4 & 4 & Power & 0,5968 \\
\hline
\end{tabular}

As seen on table 6 that from all the band of image satellite that were analysed, band 1 from Aqua Modis has the most optimum $\mathrm{R}^{2}$ correlation Value with value of 0,9144 compare with the value obtained for model from band 2 , band 3 , and band 4 . While band 1 and band 2 seem dominant from exponent model, whereas for band 3 and band 4 of power model has excellence compare to the other model. Based on the obtained value thus the algorithm of mathematical model of salinity concentration on Sampang district can be represented with band 1 with exponential model, and the mapping result of processing math band with exponential model is shown in figure 5.

\section{CONCLUSION}

From the obtained results of satellite imagery mapping towards the salinity value of Sampang district, satellite imagery can be used with a resolution of 500 meters such as Aqua Modis, in which Aqua Modis satellite imagery has the ability to map by relying on algorithms of mathematical model obtained from reflectance analysis on various bands there is. And from the Aqua Modis band, it was concluded that band 1 was the most optimum band for mapping salinity values so that in the future band 1 could be used as a benchmark for predicting salinity values in previous years or predisposing for the next year as long as there were no physical changes from the coast beach and from the climate because the calculated parameters for the mathematical model are only based on the reflectance value of the satellite image which is strongly influenced by climate and tides.

\section{ACKNOWLEDGMENT}

The author would like to thank the Institute of Research and Community Service (LPPM) of UPN "Veteran" East Java who have provided research funding assistance so that this research can take place properly and on time, also to civil engineering students of UPN who have assisted as surveyors in the field.

\section{REFERENCES}

[1] N. Al-Naimi, D. Raitsos, R. Ben-Hamadou, and Y. Soliman, "Evaluation of Satellite Retrievals of Chlorophyll-a in the Arabian Gulf," Remote Sens., vol. 9, pp. 301, 2017.

[2] P. Dorji and P. Fearns, "A Quantitative Comparison of Total Suspended Sediment Algorithms: A Case Study of the Last Decade for MODIS and Landsat-Based Sensors," Remote Sens., vol. 8, pp. 810, 2016.

[3] P. Etnoyer, D. Canny, B.R. Mate, L.E. Morgan, J.G. Ortega-Ortiz, and W.J. Nichols, "Sea-surface temperature gradients across blue whale and sea turtle foraging trajectories off the Baja California Peninsula, Mexico," Deep-Sea Res. Part II: Topic. Studies Oceanogr., vol. 53, pp. 340-358, 2006

[4] M. Fauzi and P. Wicaksono, "Total Suspended Solid (TSS) Mapping of Wadaslintang Reservoir Using Landsat 8 OLI,” IOP Conf. Ser. Earth Environ. Sci., vol. 47, pp. 012029, 2016.

[5] Z. Honglei, Z. Yanmin, W. Xi., Z. Yunhua, and M. Junmin, "The polarimetric features of oil spills in full polarimetric synthetic aperture radar images," Acta Oceanol. Sin., vol. 36, pp. 105-114, 2017.

[6] J. Laliberté, P. Larouche, E. Devred, and S. Craig, "Chlorophyll-a Concentration Retrieval in the Optically Complex Waters of the St. Lawrence Estuary and Gulf Using Principal Component Analysis," Remote Sens., vol. 10, pp. 265, 2018.

[7] L.E.E.H. Lee, T. Fredolin, G.J. Isabella, and S. Saim, "Prediction of salinity intrusion in the sheltered estuary of Terengganu River in Malaysia using 1-D empirical intrusion model," Acta Oceanol. Sin., vol. 36, pp. 57-66, 2017.

[8] A. Olita, A. Cucco, S. Simeone, A. Ribotti, L. Fazioli, B. Sorgente, and R. Sorgente, "Oil spill hazard and risk assessment for the shorelines of a Mediterranean coastal archipelago," Ocean Coast. Manag., vol. 57, pp. 44-52, 2012.

[9] J. She, J. F. Wang, and J. Zhou, "A Novel Sensor Selection and Power Allocation Algorithm for Multiple-Target Tracking in an LPI Radar Network," Sens., vol. 16, pp. 2193, 2016. 
[10] R.A. Shuchman, G. Leshkevich, M.J. Sayers, T.H. Johengen, C.N. Brooks, and D. Pozdnyakov, "An algorithm to retrieve chlorophyll, dissolved organic carbon, and suspended minerals from Great Lakes satellite data," J. Gt. Lakes Res., vol. 39, pp. 14-33, 2013.

[11] H. Van der Woerd and M. Wernand, "Hue-Angle Product for Low to Medium Spatial Resolution Optical Satellite Sensors," Rem. Sens., vol. 10, pp. 180, 2018.

[12] Z. Wang, K. Kawamura, Y. Sakuno, X. Fan, Z. Gong, and J. Lim, "Retrieval of Chlorophyll-a and Total Suspended Solids Using Iterative Stepwise Elimination Partial Least Squares (ISE-PLS) Regression Based on Field Hyperspectral Measurements in Irrigation Ponds in Higashihiroshima, Japan,” Rem. Sens., vol. 9, pp. 264, 2017.

[13] H. Wibisana, and S. Zainab, "Time Series Analysis of Sea Surface Temperature With Aqua MODIS from 2011 to 2016. Case Studi: North Coast of Gresik and Madura," IPTEK J. Technol. Sci. vol. 28, pp. 15-19, 2017.
[14] G.A. Wisnu, and J. Ulung Wisha, "Spatial Distribution of Surface Salinity and Temperature In Brebes Seawater: Its Effects on the Other Water Quality Parameters," J. Ilm. Geomatika, vol. 23, pp. 8-16, 2017.

[15] H.H. Yen, "Optimization-Based Channel Constrained Data Aggregation Routing Algorithms in Multi-Radio Wireless Sensor Networks," Sens., vol. 9, pp. 4766-4788, 2009.

[16] H. Yu, M. Liu, B. Du, Z. Wang, L. Hu, and B. Zhang, "Mapping Soil Salinity/Sodicity by using Landsat OLI Imagery and PLSR Algorithm over Semiarid West Jilin Province, China," Sens., vol. 18, pp. 1048, 2018.

[17] Z. Zheng, Y. Li, Y. Guo, Y. Xu, G. Liu, and C. Du, "Landsat-Based Long-Term Monitoring of Total Suspended Matter Concentration Pattern Change in the Wet Season for Dongting Lake, China," Rem. Sens., vol. 7, pp. 13975-13999, 2015. 